\title{
A Logistic Regression Model of Customer Satisfaction of Airline
}

\author{
Peter Josephat (Corresponding author) \\ Dept. of Statistics, University of Dodoma \\ P. O. Box 338, Dodoma, Tanzania \\ E-mail:mtakwimu@yahoo.com \\ Abbas Ismail \\ Dept. of Statistics, University of Dodoma \\ P. O. Box 338, Dodoma, Tanzania \\ E-mail: abbasism2003@yahoo.co.uk
}

Accepted: November 05, 2012 Published: December 14, 2012

Doi:10.5296/ijhrs.v2i4.2868

URL: http://dx.doi.org/10.5296/ijhrs.v2i4.2868

\begin{abstract}
Evaluation of customer satisfaction differs from one study to another. Studies have been differing with their focus and coverage. Most of studies focused on evaluating factors influencing customer satisfaction or associate customer satisfaction and quality of services. This paper used logistic regression to develop customer satisfaction model for Precision Air. Five dimensions or variables have been considered: on time performance; aircraft safety; schedule integrity; on board services; and customer service.
\end{abstract}

Data used in this paper were collected from four major regions with many flights. These include Dar es Salaam, Mwanza, Arusha and Kilimanjaro. A sample size of 272 passengers was selected. Convenience sampling was used to select the respondents. Primary data were collected in the field through questionnaire. Findings showed that out of the five independent variables only one variable is negatively related with satisfaction of airline passengers (customer services). In contrast, on time performance was satisfactory variable by most of passengers compared to the rest of explanatory variables. Airline safety, schedule integrity and on board services are positively related with passengers satisfaction. Relationship between customer services and satisfaction are negatively related which implies that, there is a need of finding strategies to improve customer services to customers. The paper recommends that the airline should maintain and improve on time performance as this is crucial variable for passenger's satisfaction but other variables need more improvement.

Keywords: Logistic, Logit, Dimension, On Time Performance, Aircraft Safety, Schedule Integrity, On Board Services, Customer Service 


\subsection{Introduction}

In this era of liberalized economy, government intervention has been very minimal as market economy prevails. Producers can decide what to produce or not. Many private owned firms and companies have been established mainly to earn profit. On the other hand, people are free to choose services which they want. Because of competition in the market, it has been realized that customer satisfaction plays major role to keep companies in the line of business. Satisfaction is the feeling of someone who described feeling happy or disappointed that the result of comparing the perceived performance of a product with the expected product performance (Kotler, 2003 cited in Rizan, 2010).

Importance of making customers satisfied has no bound i.e. it involves all firms and companies including airlines. Degirmenci et al. (2012) stated that "airline companies have realized the importance of satisfied customers to find a place for themselves in this competitive world and initiated many projects to measure service quality and satisfy the customers by improving service quality".

In Tanzania there are at least six airlines based in the country such as Air Tanzania, Auric Air, Coastal Aviation, Precision Air, Regional Air services and Zan Air. Other airline which operates in the country includes Fyl540, Kenya Airways to mention few. By April 2012, there were 57 licenced air operators in the country. Out of 57 about 17 airlines were not operating by that time (Sumila, 2007) which is 29.8\%. Low cost African airline FastJet has confirmed to commence flying in November 2012. The airline will drive down prices in the existing market. Many flights from different airlines imply competition in which each airline should make sure they win satisfaction of their customers to ensure they stay in a line of business. This suggests that there is a need of thoroughly studies to measure customer satisfaction.

Customer satisfaction in airline operations has become critically important (Clemes et al., 2008). It is from this fact the airline started to offer various incentives e.g. brochures, competitive prices and computerized reservation system with purpose of creating customer loyalty (Clemes et al., 2008). Ostrowski et al. (1993) cited in Clemes et al. (2008) cautioned that if it happen that all airlines are similar in terms of incentives, the company with better perceived service will capture passenger from other airlines.

There have been different methodology and statistical techniques used to measure customer satisfaction. Customer evaluations on service are highly dynamic, complex, and subjective in nature (Yoo and Park, 2007). Some of the techniques used include weighted SERVQUAL adopted by Degirmenci et al. (2012), SERVQUAL, regression analysis used by Shahin and Janatyan (2011), Rasch model used by Nicolini and Salini (2006), pearson correlation used by Oyewole et al. (2007). Furthermore descriptive analysis has been adapted to measure customer satisfaction. Rizan (2010) mentioned five approaches that were outlined by Diah (2000) which are used to measure customer satisfaction: paradigm of disconfirmation 
expectations; theory of comparative level; equity theory; norms as a benchmark standard; and theory of perceptual disparity value.

Evaluation of customer satisfaction differs from one study to another. Studies have been differing with their focus and coverage. Most of studies focused on evaluating factors influencing customer satisfaction or associate customer satisfaction and quality of services. This paper use logistic regression to develop customer satisfaction model for Precision Air. Five dimensions have been considered: on time performance; aircraft safety; schedule integrity; on board services; and customer service. This paper contribute into literature methodological knowledge on measuring and determine customer satisfaction of an organization taking into account limited inferential analysis of satisfaction in the airline industry in the country.

\subsection{Logistic Regression}

Logistic regression is extension of linear regression used to predict dichotomous dependent variable. It is applied when the relationship between dependent variable and independent variables (s) is nonlinear. Linearity is considered to be in logit. Logistic regression predict likelihood that $Y=1$ and not 0 given certain values of $X$. This implies that if $X$ and $Y$ are linear related, probability of $Y=1$ increase as value of $\mathrm{X}$ increases. If this is a case, interest is to predict probabilities rather than the scores of dependent variables (Fall, 2011). Likelihood of the data set as the product across all cases of the probabilities is;

$$
\begin{gathered}
L=\prod_{i=1}^{n i} P\left(Y_{i} / X_{i 1}, \ldots, X_{i p}\right) \\
=\prod_{i=1}^{n i}\left[\left(\frac{e^{\beta_{0}+\sum_{j=1}^{4} \beta_{j} X_{j}}}{1+e^{\beta_{0}+\sum_{j=1}^{4} \beta_{j} X_{j}}}\right)^{Y_{i}} x\left(\frac{1}{1+e^{\beta_{0}+\sum_{j=1}^{4} \beta_{j} X_{j}}}\right)^{1-Y_{i}}\right]
\end{gathered}
$$

Where by $Y$ is the 0 or 1 outcome for the $i^{\text {th }}$ case and, $x_{i 1} \ldots x_{i p}$ are the values of the predictor variables for the $i^{\text {th }}$ case based on a sample of n cases. The use of $Y_{i}$ and $1-Y_{i}$ as exponents in the equation above included in the likelihood the appropriate probability term dependent upon whether $Y_{i}=1$ or $Y_{i}=0$ (Mosha and Josephat, 2011).

Assumptions for logistic regression differ to that of linear regression. In order to have prediction model like that of linear regression there is a need of manipulating the logistic regression model which is commonly called logit (natural logarithm of an odds ratio). 
Simplified logistic regression model is $\operatorname{Logit}(\mathrm{Y})=\ln ($ odds $)=\ln \left(\frac{\hat{p}}{1-\hat{p}}\right)=\alpha+\beta X$

$\hat{p}$ stand for probability that $\mathrm{Y}$ is 1 while $1-\hat{p}$ stand for $\mathrm{Y}$ is 0 .

$$
\hat{p}=\frac{\exp (\alpha+\beta X)}{1+\exp (\alpha+\beta X)}
$$

The paper used logistic regression technique to develop customer satisfaction model basing from the fact that both dependent and independent variables are categorical. Response for dependent variable was Yes or No while response for all independent variables was categorical. Prediction of customer satisfaction is done using five dimensions with assumptions that as satisfaction of the five drivers increase, overall satisfaction is also increasing.

\subsection{Precision Air}

Precision air has been selected because currently is the leading airline in the country despite being the private owned airline. It is leading in terms of schedules, charter and scenic flights. Mission of the airline is to develop and provide a superior air transport service that exceeds customer expectations. Vision of the airline is to be the airline of choice. From the mission and vision it can be observed that the airline is customer focused. Basing on the five dimensions, the paper focused on Precision air to test to what extent the customer has been satisfied using inferential analysis.

Precision air started to operate in 1993 and it based in Dar es Salaam. Currently about 58\% of shareholders of the airline is owned by Tanzanians, $41 \%$ Kenya Airways and $1 \%$ by other nationals. The airline operates scheduled passenger air services within the country and outside the country. Flights in the country includes: Dar es Salaam, Kilimanjaro, Zanzibar, Mwanza, Musoma, Bukoba, Kigoma, Mtwara, Arusha and Shinyanga. International flights includes: Mombasa, Entebbe, Comoros, Nairobi, Lusaka and Lubumbashi (Precision air, 2012).

\subsection{Material and Methods}

\subsection{Study Area}

Data used in this paper were collected from four major regions with many flights. These include Dar es Salaam, Mwanza, Arusha and Kilimanjaro. Despite that, there is flights competition in these routes. The study was not interested in the region or route where precision air is monopoly.

\subsection{Population and Sample Size}

The target population was people who flight with precision air between Dar es Salaam, Arusha, Kilimanjaro and Mwanza. The population included on board passengers and frequent 


\section{Macrothink}

fliers members. A sample size of 272 passengers was selected. Convenience sampling was used to select the respondents.

\subsection{Data Collection and Analysis}

The study used primary data which were collected in the field through questionnaire. Data were analysed using Statistical Package for Social Sciences (SPSS) version 17. Analysis was done using logistic regression to determine importance of the factors that influence customer satisfaction. At first, cross tabulation was conducted to find relationship of variables. A chi-square test was used to indicate how well the logistic regression model fits the data. Thereafter, logistic regression coefficients were estimated using the following likelihood ration model;

$$
\begin{gathered}
\log _{e}\left[\frac{P\left(Y=1 / X_{1}, X_{2}, \ldots, X_{5}\right)}{1-P\left(Y=1 / X_{1}, X_{2}, \ldots, X_{5}\right)}\right]=\log _{e}\left[\frac{\pi}{1-\pi}\right]=\alpha+\beta_{1} X_{1}+\ldots+\beta_{5} X_{5} \\
=\alpha+\sum_{j=1}^{5} \beta_{j} X_{j}
\end{gathered}
$$

Where:

$Y=$ customer satisfaction; $X_{1}=$ on time performance; $X_{2}=$ aircraft safety; $X_{3}=$ schedule integrity; $X_{4}=$ on board services; and $X_{5}=$ customer service.

\section{Results and Discussion}

\subsection{Cross Tabulation}

Cross tabulation result are presented in appendix I. From the result, conditional probability of passengers being satisfied by on time performance is $117 / 135=0.867$ while conditional probability of being dissatisfied is $28 / 53=0.528$. This result suggest that on time performance dimension has much influence of making passengers to be satisfied rather than being dissatisfied. Condition probability for passengers being satisfied by aircraft safety is $110 / 133=0.827$, schedule integrity is $108 / 126=0.857$, on board services is $114 / 135=0.844$ and customer services is $77 / 100=0.77$. All these dimensions favour satisfaction of passengers.

Odds of on time performance to influence satisfaction of passengers is $117 / 18=6.5$. This implies that chance of passengers being satisfied by on time performance is 6.5 to 1 . Odds of satisfaction on aircraft safety, schedule integrity, on board services and customer service are $110 / 23=4.78,108 / 18=6,114 / 21=5.43$ and $77 / 23=3.35$ respectively .

\subsection{Logistic Regression Model}

Out of 272 respondents about 222 were involved in modelling as other cases are deleted for having missing information. This is $81.6 \%$ of targeted sample size. Sample size used to run 


\section{Macrothink}

International Journal of Human Resource Studies

ISSN 2162-3058

2012, Vol. 2, No. 4

logistic analysis is satisfactory. Pampel (2000) and Long (1997) recommended sample size for logistic regression analysis not to be less than 100 otherwise the result will be misleading. A minimum of 50 cases per independent variable is recommended (Wright, 1995). In all cases sample size used fulfil the requirement.

Enter method has been selected in order to get stable regression coefficients as sample size is not that much large. Though enter method, all variables are entered in one single step without checking. This suit this paper as the focus was modelling rather than looking significance of the dimensions. It could not be proper to drop any variable as theoretically these dimensions influence satisfaction.

Beginning block which comprised constant reduced model showed that correct percentage is $78.4 \%$. This correctness percent is when independent variables are excluded. Table 1 present Omnibus Tests of model coefficients. This result is when independent variables are taken into account. In this table the interest is to look contribution of initial predictors adds above or beyond correct percent to the constant model.

Table 1: Omnibus Tests of Model Coefficients

\begin{tabular}{|l|r|r|r|}
\hline & \multicolumn{1}{|c|}{ Chi-square } & \multicolumn{1}{c|}{ df } & \multicolumn{1}{c|}{ Sig. } \\
\hline Step & 25.239 & 5 & .000 \\
\hline Block & 25.239 & 5 & .000 \\
\hline Model & 25.239 & 5 & .000 \\
\hline
\end{tabular}

Five variables (on time performance; aircraft safety; schedule integrity; on board services; and customer service) have been added to the model. By adding these variables, -2log likelihood (deviance) has reduced by 25.239 on 5 degree of freedom which implies that there is much variations of airline passenger satisfaction. Looking $p$ value of step, block and model it can be seen that these items are significant $(<0.05)$. This concludes that the additions of the independent variables to the model are statistically significant. This shows that the independent variables explain variations in satisfaction.

Cox \& Snell R Square and Nagelkerke R Square indicate that the model which includes the five independents variables explains between $10.7 \%$ and $16.6 \%$ of the variation in satisfaction. From Table 2, it can be seen that only on time performance variable is significant $(\mathrm{sig}=0.006<0.05)$ while others are insignificant. 


\section{MInstitute Machink $_{\text {inth }}$}

Table 2: Variables in the equation

\begin{tabular}{|l|r|r|r|r|r|r|r|r|}
\hline & \multirow{2}{*}{ B } & S.E. & Wald & df & Sig. & \multirow{2}{*}{$\operatorname{Exp}(\mathrm{B})$} & \multicolumn{2}{|c|}{ 95\% C.I. for EXP(B) } \\
\cline { 8 - 10 } & & & & & & & Lower & \multicolumn{1}{c|}{ Upper } \\
\hline On time performance & 1.457 & .532 & 7.500 & 1 & .006 & 4.295 & 1.513 & 12.188 \\
\hline Aircraft safety & .090 & .543 & .027 & 1 & .869 & 1.094 & .377 & 3.171 \\
\hline Schedule integrity & .407 & .486 & .701 & 1 & .402 & 1.502 & .580 & 3.892 \\
\hline On board services & .158 & .440 & .129 & 1 & .719 & 1.172 & .494 & 2.778 \\
\hline Customer care & -.222 & .456 & .237 & 1 & .626 & .801 & .327 & 1.958 \\
\hline Constant & .005 & .486 & .000 & 1 & .992 & 1.005 & & \\
\hline
\end{tabular}

The Exp (B) column presents odds ratio and indicates that excellent on time performance is 4.295 times more likely to make passengers satisfied than being dissatisfied. Excellent aircraft safety is 1.094 times more likely to make passengers satisfied than being dissatisfied, excellent schedule integrity is 1.502 times more likely to make passengers satisfied than being dissatisfied. Moreover, on board services was 1.172 times more likely to make passengers satisfied than being dissatisfied while customer services was 0.801 times more likely to make passengers satisfied than being dissatisfied.

Confidence interval for on time performance is 1.513 to 12.188 which indicates that excellent on time performance is between 1.513 to 12.188 times as likely to make passenger satisfied that being not satisfied. This variable has higher confidence interval compared to other variables. This is because it is the only variable which is significant. This shows that the variable has explanatory power compared to others.

The table above shows that the estimated model is now:

$$
\operatorname{Logit}(Y)=0.005+1.457 X_{1}+0.090 X_{2}+0.407 X_{3}+0.158 X_{4}-0.222 X_{5}
$$

Whereby;

$Y=$ Satisfaction, $X_{1}=$ on time performance, $X_{2}=$ aircraft safety, $X_{3}=$ Schedule

integrity, $X_{4}=$ On board services and $X_{5}=$ Customer services.

From the model it can be seen that, on time performance, aircraft safety, schedule integrity and on board services are positive related to passengers satisfaction because of positive sign. Furthermore, since their odds ratio is greater than 1. One variable, customer satisfaction has negative relationship with satisfaction as its odds ratio is below 1 . 


\section{Conclusion and Recommendation}

Findings showed that out of the five independent variables only one variable is negatively related to satisfaction of airline passengers (customer services). On time performance is the independent variable which makes most passengers to be satisfied compared to others. Airline safety, schedule integrity and on board services are positively related with passengers satisfaction.

Relationship between customer services and satisfaction are negatively related which implies that, there is a need of finding strategies to improve customer services to customers. This should be done because if it stays as it is, level of satisfaction is eroded by 0.222 . On the other hand, the paper recommends that the airline should maintain and improve on time performance this is crucial variable for passenger's satisfaction. Other variables need improvement too.

\section{Acknowledgement}

The authors wish to acknowledge Julliette James as data used in this paper were collected in her study.

\section{Competing Interests}

We declare that the authors have no competing interests or other interests that might influence the findings in this paper.

\section{Corresponding Author}

Peter Josephat (Corresponding author)

Dept. of Statistics, University of Dodoma

P. O. Box 338, Dodoma, Tanzania

Mobile: 255-0787288998 E-mail: mtakwimu@yahoo.com

\section{References}

Clemes, M. D., Gan, C., Kao, T. and Choong, M. (2008). An Empirical Analysis of Customer Satisfaction in International Air Travel. Innovative Marketing, Volume 4, Issue 2.

Degirmenci, E., Basligil, H., Bolat A. and Ozdemir, Y. (2012). Customer Satisfaction Measurement in Airline Services Using Servqual. 1: 294. doi:10.4172/scientificreports.294.

Diah, N. (2000). "Pengaruh Komitmen Manajemen Terhadap Kualitas Layanan Untuk Meningkatkan Kepuasan Pelanggan Maskapai Penerbangan Domestik: Sudut Pandang Pelanggan dan Penyaji Jasa”. Disertasi Ilmu Ekonomi, Program Pascasarjana Universitas Airlangga, Surabaya.

Fall (2011). Logistic Regression. [Online] Available: http://www.upa.pdx.edu/IOA/newsom/da2/ho_logistic.pdf (November 10, 2012). 
Kotler, P. (2003). Marketing Management. Eleventh Edition. New Jersey, USA: Prentice Hall Pearson Education International Inc.

Long, J. S (1997). Regression Models for Categorical and Limited Dependent Variables. Thousand Oaks, CA: Sage Publications.

Mosha, P. E. and Josephat, P. (2011). Analysis on Gender Differences in Studying Science Subjects at the University of Dar es Salaam. Rural Planning Journal, Vol. 13 No. 2 (12):45 64.

Nicolini, G. and Salini, S. (2006). Customer Satisfaction in the Airline Industry: The Case of British Airways. Quality and Reliability Engineering International, 22, 1-9.

Ostrowski, R. L., O'Brien T. V., and Gordon G. L. (1993). Service Quality and Customer Loyalty in the Commercial Airline Industry. Journal of Travel Research, Vol. 32 (2), pp. $16-24$.

Oyewole, P., Sankaran, M. and Choudhury, P. (2007). Marketing Airline Services in Malaysia: A Consumer Satisfaction Orientation. Innovative Marketing, Volume 3, Issue 1.

Pampel, F. C (2000). Logistic regression: A primer Sage University Papers Series on Quantitative Applications in the Social Sciences, 07-132. Thousand Oaks, CA: Sage Publications.

Precision air (2012). http://www.precisionairtz.com.

Rizan, M. (2010). “Analysis of Service Quality and Customer Satisfaction, and Its Influence on Customer Loyalty”. Oxford Business \& Economics Conference Program.

Shahin, A. and Janatyan, N. (2011). Estimation of Customer Dissatisfaction Based on Service Quality Gaps by Correlation and Regression Analysis in a Travel Agency. International Journal of Business and Management Vol. 6, No. 3.

Sumila, V. (2012). Air Transport Grows Tremendously. [Online] Available: http://www.thecitizen.co.tz/magazines/31-business-week/21542-air-transport-grows-tremend ously.html (November 01, 2012).

Wright, R.E. 1995. Logistic Regression. In L. G. Grimm \& P. R. Yarnold, (Eds.), Reading and Understanding Multivariate Statistics (Pp. 217-244). Washington, DC: American Psychological Association. 


\section{Macrothink}

International Journal of Human Resource Studies

ISSN 2162-3058 2012, Vol. 2, No. 4

Yoo, D. K. and Park, J. A. (2007). Perceived service quality Analyzing relationships among employees, customers, and financial performance. International Journal of Quality \& Reliability Management Vol. 24 No. 9: 908-926. 
Appendix I: Cross tabulation output of satisfaction against independent variables

\begin{tabular}{|c|c|c|c|c|c|}
\hline \multirow{2}{*}{ Dimension } & & & \multicolumn{2}{|c|}{ Satisfaction } & \multirow[t]{2}{*}{ Total } \\
\hline & & & No & Yes & \\
\hline \multirow{6}{*}{$\begin{array}{l}\text { On time } \\
\text { performance }\end{array}$} & \multirow[t]{2}{*}{ Dissatisfied } & Count & 25 & 28 & 53 \\
\hline & & $\%$ within On time performance & $47.2 \%$ & $52.8 \%$ & $100.0 \%$ \\
\hline & \multirow[t]{2}{*}{ Satisfied } & Count & 18 & 117 & 135 \\
\hline & & $\%$ within On time performance & $13.3 \%$ & $86.7 \%$ & $100.0 \%$ \\
\hline & \multirow[t]{2}{*}{ Total } & Count & 43 & 145 & 188 \\
\hline & & $\%$ within On time performance & $22.9 \%$ & $77.1 \%$ & $100.0 \%$ \\
\hline \multirow{6}{*}{$\begin{array}{l}\text { Aircraft } \\
\text { safety }\end{array}$} & \multirow[t]{2}{*}{ Dissatisfied } & Count & 9 & 15 & 24 \\
\hline & & $\%$ within Aircraft safety & $37.5 \%$ & $\begin{array}{r}62.5 \\
\% \\
\end{array}$ & $100.0 \%$ \\
\hline & \multirow[t]{2}{*}{ Satisfied } & Count & 23 & 110 & 133 \\
\hline & & $\%$ within Aircraft safety & $17.3 \%$ & $\begin{array}{r}82.7 \\
\% \\
\end{array}$ & $100.0 \%$ \\
\hline & \multirow[t]{2}{*}{ Total } & Count & 32 & 125 & 157 \\
\hline & & $\%$ within Aircraft safety & $20.4 \%$ & $\begin{array}{r}79.6 \\
\% \\
\end{array}$ & $100.0 \%$ \\
\hline \multirow{6}{*}{$\begin{array}{l}\text { Schedule } \\
\text { integrity }\end{array}$} & \multirow[t]{2}{*}{ Dissatisfied } & Count & 24 & 35 & 59 \\
\hline & & $\%$ within Schedule integrity & $40.7 \%$ & $59.3 \%$ & $100.0 \%$ \\
\hline & \multirow[t]{2}{*}{ Satisfied } & Count & 18 & 108 & 126 \\
\hline & & $\%$ within Schedule integrity & $14.3 \%$ & $85.7 \%$ & $100.0 \%$ \\
\hline & \multirow[t]{2}{*}{ Total } & Count & 42 & 143 & 185 \\
\hline & & $\%$ within Schedule integrity & $22.7 \%$ & $77.3 \%$ & $100.0 \%$ \\
\hline \multirow{6}{*}{$\begin{array}{l}\text { On board } \\
\text { services }\end{array}$} & \multirow[t]{2}{*}{ Dissatisfied } & Count & 18 & 33 & 51 \\
\hline & & $\%$ within On board services & $35.3 \%$ & $64.7 \%$ & $100.0 \%$ \\
\hline & \multirow[t]{2}{*}{ Satisfied } & Count & 21 & 114 & 135 \\
\hline & & $\%$ within On board services & $15.6 \%$ & $84.4 \%$ & $100.0 \%$ \\
\hline & \multirow[t]{2}{*}{ Total } & Count & 39 & 147 & 186 \\
\hline & & $\%$ within On board services & $21.0 \%$ & $79.0 \%$ & $100.0 \%$ \\
\hline \multirow{6}{*}{$\begin{array}{l}\text { Customer } \\
\text { service }\end{array}$} & \multirow[t]{2}{*}{ Dissatisfied } & Count & 15 & 34 & 49 \\
\hline & & $\%$ within Customer service & $30.6 \%$ & $69.4 \%$ & $100.0 \%$ \\
\hline & \multirow[t]{2}{*}{ Satisfied } & Count & 23 & 77 & 100 \\
\hline & & $\%$ within Customer service & $23.0 \%$ & $77.0 \%$ & $100.0 \%$ \\
\hline & \multirow[t]{2}{*}{ Total } & Count & 38 & 111 & 149 \\
\hline & & $\%$ within Customer service & $25.5 \%$ & $74.5 \%$ & $100.0 \%$ \\
\hline
\end{tabular}

